\title{
KEKUATAN DAN DAKTILITAS PERPINDAHAN KOLOM PENDEK BETON BERTULANG PERSEGI DIBAWAH PENGARUH PEMBEBANAN SIKLIK
}

\begin{abstract}
Parmo
Abstract: Indonesia menempati zona tektonik yang sangat aktifsehingga sangat rawanterhadapgempabumi. Oleh karena itu perencanaan elemen struktur bangunan gedung sangatlah perlu memperhatikan kekuatan dan juga daktilitas. Kekuatan struktur berfungsi menahan beban oleh adanya gaya gravitasi sedangkan daktilitas merupakan salah satu persyaratan struktur tahan gempa, sedangkan pembebanan siklik merupakan representasi yang tepat untuk menggambarkan beban dinamis yang terjadi. Kolom merupakan komponen struktur yang berperan penting untuk mendukung beban aksial, beban gempa, momen lentur dan gaya geser. Karena keruntuhan kolom bisa mengakibatkan struktur bangunan runtuh (collapse) secara keseluruhan. Dalam penelitian ini diuji 1 buah kolom masing-masing berpenampang persegi, dengan ukuran tinggi $350 \mathrm{~mm}$, lebar $350 \mathrm{~mm}$ dan panjang $1100 \mathrm{~mm}$. Kuat tekan beton rata-rata digunakan $\mathrm{f}^{\prime} \mathrm{c}=20,34 \mathrm{Mpa}$, tegangan leleh tulangan baja longitudinal fy $=549,94 \mathrm{Mpa}$. Pengujian dilakukan dengan memberikan beban aksial konstan $748 \mathrm{kN}$ dan beban lateral siklik metode displacemet control untuk mensimulasikan beban gempa. Hasil analisa tioritis diagram interaksi sebagai representasi kekuatan kolom secara teoritis diperoleh beban horizontal $\left(\mathrm{P}_{\mathrm{h}}\right)$ dan momen yang secara teroritis diperoleh $\mathrm{P}_{\mathrm{h}}$ sebesar $185,73 \mathrm{kN}$ dan momen nominal kolom secara teoritis diperoleh $202,45 \mathrm{kN}$.m sedangkan pengujian ekperimental diperoleh $\mathrm{P}_{\mathrm{h} \text { maks }}$ sebesar 288,0 $\mathrm{kN}$ dengan momen nominal sebesar 316,8 kN.m. Nilai Daktilitas kolom diperoleh setelah benda uji dilakukan pengujian siklik dan hasil pengujian dilakukan analisis. Daktilitas perpindahan $(\mu \Delta)$ kolom uji C-1 sebesar 2,71, sehingga kolom termasuk daktail parsial.
\end{abstract}

Kata kunci: kolom beton bertulang, kekuatan, daktilitas.

Indonesia menempati zona tektonik yang sangat aktif karena tiga lempeng besar dunia dan sembilan lempeng kecil lainnya saling bertemu di wilayah Indonesia dan membentuk jalur-jalur pertemuan lempeng yang kompleks. Keberadaan interaksiantar lempeng-lempeng ini menempatkan wilayah Indonesias ebagai wilayah yang sangat rawan terhadap gempa bumi. Tingginya aktivitas kegempaan ini terlihat dari hasil pencatatan dimana dalam rentang waktu 1897-2009 terdapat lebih dari 14.000 kejadian gempa dengan magnitude $M>5.0$. Gempa bumi yang terjadi di Indonesia dan di dunia telah menyebabkan jutaan korban jiwa, keruntuhan dan kerusakan ribuan infrastruktur dan bangunan, serta dana trilyunan rupiah untuk rehabilitasi dan rekonstruksi (Tim revisi peta gempa Indonesia, 2010). Untuk meminimalkan akibat yang ditimbulkan oleh adanya gempa dapat berupa: 1) penyediaan peralatan emergency (keadaan darurat); 2) tempat tinggal atau bangunan yang tahan gempa; dan 3) prediksi terhadap gempa (Khrisnamurti, 2009).

Suatu struktur bangunan dikatakan kuat apabila dia mampu menyokong bebanbeban yang ada diatasnya. Kekuatan struktur ditentukan oleh kualitas material, dimensi dan kombinasi penyusun struktur tersebut, apabila beton bertulang kekuatan struktur ditentukan oleh kualitas beton, kualitas baja, dimensi dan banyak sedikitnya baja tulangan. Daktilitas adalah kemampuan suatu struktur bangunan untuk mengalami simpangan pasca elastik yang besar secara berulang kali dan siklik akibat beban gempa di atas beban gempa yang menyebabkan terjadinya pelelehan pertama, sambil mempertahankan kekuatan dan kekakuan yang cukup, sehingga struktur bangunan

Parmo adalah Dosen Teknik Sipil, Fakultas Teknik, Universitas Wisnuwardhana Malang email:parmo_99@yahoo.com 
gedung tersebut tetap berdiri, walaupun sudah berada dalam kondisi plastik.Daktilitas merupakan salah satu persyaratan dasar pada struktur yang menahan pembebanan dinamis, seperti gempa bumi.Dimana pembebanan siklis merupakan model representatif yang tepat untuk menggambarkan beban dinamis yang terjadi.

Kolom merupakan elemen struktur yang penting karena kegagalan kolom akan berakibat langsung terhadap komponen struktur lainnya. Kegagalan ini akan berakibat fatal baik dari segi ekonomis maupun dari segi kemanusiaan (korban jiwa). Sehingga dalam suatu struktur keruntuhan kolom struktural merupakan hal yang sangat penting untuk ditinjau.

Tingkat pembebanan dan jumlah siklus sangat mempengaruhi perilaku respon tegangan-regangan beton seperti yang dinyatakan dalam model Mander dkkuntuk beton terkekang (Shao, 2003). Perkuatan eksternal FRP juga bisa berfungsi sebagai confinement eksternal yang akan meningkatkan daktilitas struktur.

Penelitian ini bertujuan untuk mengetahui berapa besar kekuatan secara teoritis dan ekperimental kolom pendek beton bertulang persegi yang dilakukan pembebanan serta untuk menegathui seberapa besar daktilitas perpindahan setelah dilakukan analisis dari data ekperimental uji siklik.

\section{Beton dan Beton Bertulang}

Beton adalah suatu campuran yang terdiri dari pasir, kerikil, batu pecah, atau agregat-agregat lain yang dicampur menjadi satu dengan suatu pasta yang terbuat dari semen dan air yang membentuk suatu massa mirip batuan. Terkadang satu atau lebih bahan aditif ditambahkan untuk menghasilkan beton dengan karakteristik tertentu, seperti kemudahan pengerjaan (workability), durabiitas dan waktu pengerasan.

Beton bertulang adalah suatu kombinasi antara beton dan baja, dimana tulangan baja berfungsi menyediakan kuat tarik yang tidak dimiliki oleh beton. Tulangan baja juga dapat menahan gaya tekan sehingga digunakan pada kolom dan pada berbagai kondisi lainnya (McCormac, 2003).

\section{Kolom Pendek (Kolom tak Langsing) Beton Bertulang}

Apabila kolom runtuh karena kegagalan materialnya (yaitu lelehnya baja atau hancurnya beton), kolom diklasifikasikan sebagai kolom tak langsing (non slender column).Apabila panjang kolom bertambah, kemungkinan kolom runtuh karena tekuk semakin besar. Dengan demikian ada suatu transisi dari kolom tak langsing (runtuh karena material) ke kolom langsing (runtuh karena tekuk) yang terdefinisi dengan menggunakan perbandingan panjang efektif $k l_{\alpha}$ dengan jari-jari girasi $r$. Tinggi $L_{u}$ adalah panjang tak tertumpu (unsupported length) kolom, ,seperti yang ditunjukkan gambar 1 Dimana nilai $k l_{w} / r$ disebut sebagai angka kelangsingan.
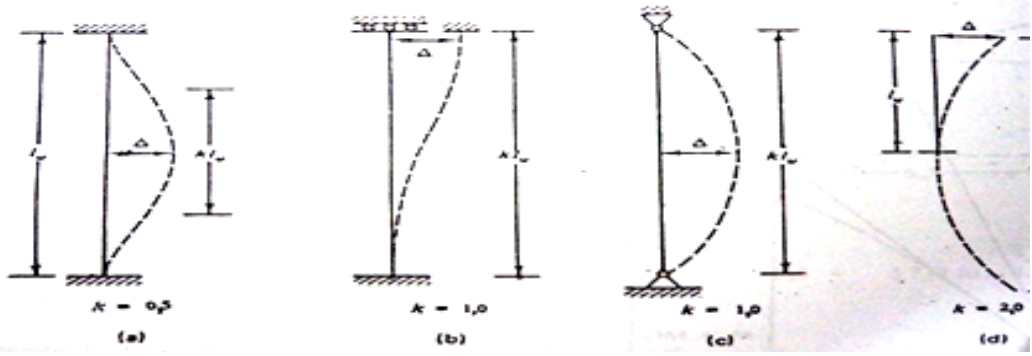

Gambar 1. Besar faktor panjang kolom untuk kondisi : (a) Jepit-jepit; (b) Jepit- jepit elastis; (c) Sendi-sendi; (d) Jepit-bebas

Kekuatan Dan Daktilitas Perpindahan Kolom Pendek Beton Bertulang Persegi Dibawah Pengaruh Pembebanan Siklik 
Identifikasi angka kelangsingan untuk kolom pendek adalah sebagai berikut :

a) Kolom yang bergoyang/tanpa pengaku (unbraced) : $\frac{k L_{r}}{r} \leq 22$

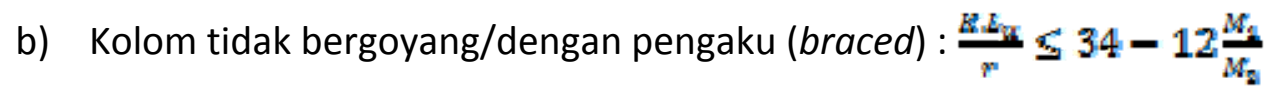

\section{Kekuatan dan Daktilitas Kolom}

\section{Kekuatan}

Kolom dapat dikekang untuk meningkatkan daya dukung aksial. Kapasitas nominal beban aksial teoritis dari kolom non-slender adalah:

$$
P_{n(m a k s)}=0,80\left[0,85 \psi_{f} f_{c c}^{\prime}\left(A_{g}-A_{s t}\right)+f_{y} A_{s t}\right]
$$

Dimana, $A_{g}=$ luas bruto beton, $A_{s t}=$ luasan tulangan memanjang baja, $f_{y}=$ tegangan leleh baja longitudinal, $\psi_{f}=$ faktor reduksi FRP, dan $f^{\prime}{ }_{c c}=$ kuattekan beton terkekang. Kapasitas aksial nominal maksimum kolom nonslender perkuatan FRP dengan pengekangantied adalah:

$f^{\prime}{ }_{c c}=f^{\prime}{ }_{c}\left(2,25 \sqrt{1+7,9 \frac{f_{l}}{f_{c}^{\prime}}}-2 \frac{f_{l}}{{f^{\prime}}_{c}}-1,25\right)$

Dalam desain hanya kekuatan pengekangan maksimum dan regangan yang diperlukan.Menurut ACI 440.2R-02 [7] kekuatan tekan pengekangan, $f_{c c}^{\prime}$ yang merupakan persamaan kekuatan beton terkekangyang dikembangkan oleh Mander $\operatorname{dkk}(1988)$ adalah:

$f_{c c}^{\prime}=f_{c}^{\prime}\left(2,25 \sqrt{1+7,9 \frac{f_{l}}{f_{c}}}-2 \frac{f_{l}}{f_{\prime_{c}}}-1,25\right)$

Dimana tekanan pengekangan disediakan oleh FRP, $f_{l}$ oleh ACI 440.2R-02 dirumuskan sebagai:

$$
f_{l}=\frac{\kappa_{a} \rho_{f} E_{f} \varepsilon_{f e}}{2}
$$

$\kappa_{a}$ merupakanfaktor efisiensi yang tergantung dari bentuk kolom, untuk kolom persegi besarnya adalah:

$$
\kappa_{a}=1-\frac{(b-2 r)^{2}+(h-2 r)^{2}}{3 b h\left(1-\rho_{g}\right)}
$$

$\mu_{g}$ adalah Rasio perkuatan kotor untuk kolom persegi, dengan syarat $k \neq t \leq 1,5$ serta $b$ dan $h$ lebih kecil dari 36 in dirumuskan:

$\rho_{g}=\frac{\left(A_{S}+A_{S}^{\prime}\right)}{A_{g}}$

$\operatorname{dan}_{P_{F}}$ untuk kolom persegi dirumuskan:

$\rho_{f}=\frac{2 n t_{f}(b+h)}{b h}$ 


\section{Daktilitas}

Berbagai parameter daktilitas pada struktur beton bertulang seperti pada gambar 2 . Termasuk didalam parameter daktilitas ini adalah curvature ductility factor $\left(\mu_{\phi}\right)$, cumulative ductility ratio $\left(N_{\phi}\right)$ danenergy damage indicator $(E)$. Semua istilah yang didefinisikan dalamGambar. 2 kecuali $L_{f}$ adalah panjang sendi plastis yang mewakili panjangwilayah paling rusak yang diukur dari pengujian dan hyang merupakan tinggi kolom. Di mana tidak ada terjadi penurunan kekuatan dan kapasitas meningkat dengan meningkatnya deformasi sampai terjadi kegagalan.Toughness/ketangguhan dan disipasi energi dapat menentukan karakteristik bagiankinerja lebih baik daripada parameter daktilitas lainnya (Sheikh, 2006).

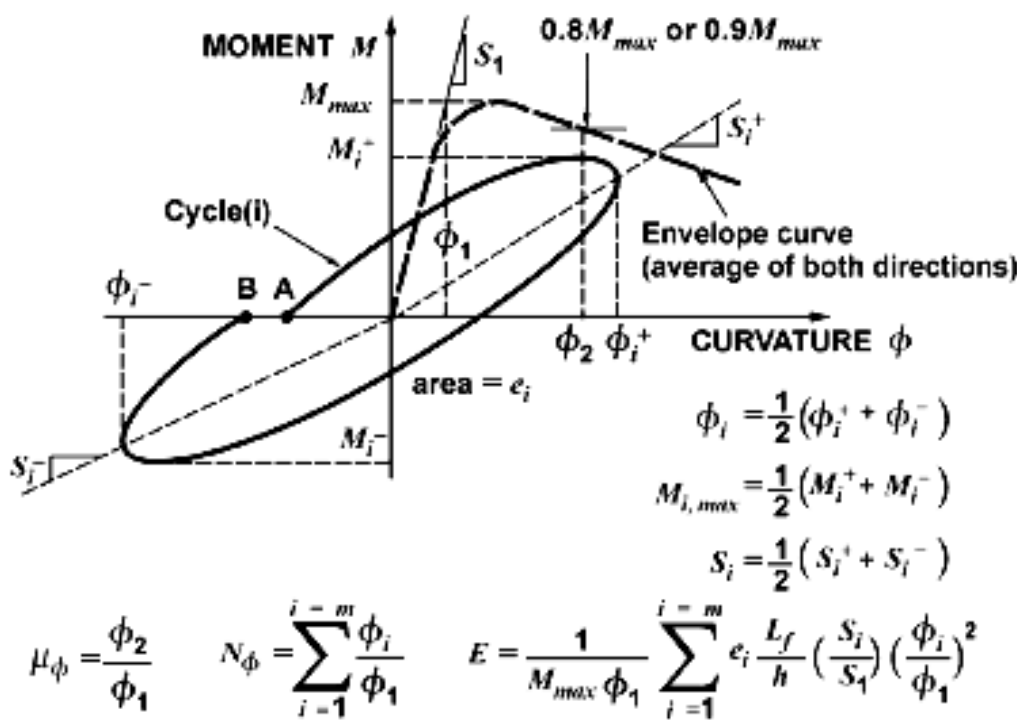

Gambar 2. Definisi dari parameter daktilitas

Parameter daktilitas yang sering digunakan untuk mengevaluasi perilaku seismik kolom termasuk faktor daktilitas kelengkungan $\mu_{\Phi}$, faktor daktilitas perpindahan $\mu_{\Delta}$ dan rasio lateral drift $\delta$.

Definisi faktor daktilitas kelengkungan $\mu_{\Phi}=\varphi_{2} / \varphi_{1}$ adalahdijelaskan dalam Gambar. 2 untuk respon momen-kelengkungan. $\varphi_{1}$ kurvatur nominal leleh adalahkelengkungan pada momen maksimum $\mathrm{M}_{\max }$ yang diukur sepanjang garis lurus menghubungkan titik asaldantitik $75 \% \mathrm{M}_{\max }$ pada kurva amplop, sementara $\varphi_{2}$ adalah kelengkungan ultimit ketika kapasitas momenpasca-puncak mengurangi sampai $80 \%$ $\mathrm{M}_{\max }$ atau pada kegagalan kolom, mana yang lebih dahulu.

Demikian pula, faktor perpindahan daktilitas $\mu_{\Delta}=\Delta_{2} / \Delta_{1}$ dan rasio lateral drift $\delta$ $=\Delta_{2} / \mathrm{L}$ jugadapatditentukan untuk kolom menggunakan respon lateral geser- defleksi tip (V- $\Delta$ ), dimana $\Delta_{1}=$ defleksi leleh nominal, $\Delta_{2}=$ defleksi sesuai dengan pengurangan $20 \%$ dalam kapasitas beban lateral padadescending branch geser-defleksienvelop curve dan $\mathrm{L}=$ panjang kolom kantileverdiukur dari bagian momen maksimum ke titik contraflexure (Sheikh \& Liu, 2010). 
Daktilitas diekspresikan sebagai faktor daktilitas atau indeks daktilitas.Faktor daktilitas didefinisikan sebagai rasio dari perpindahan maksimum dengan perpindahan leleh (Park, Paulay, 1975):

$$
\mu_{\Delta}=\frac{\Delta_{m}}{\Delta_{y}}
$$

dimana $: \mu_{\Delta}=$ faktor daktilitas ( $\Delta$ mengacu pada perpindahan)

$\Delta_{m}=$ perpindahan maksimum (respon inelastis)

$\Delta_{y}=$ perpindahan leleh

Agar faktor daktilitas lebih besar dari satu maka jumlah perpindahan maksimum, $\Delta_{m}$ (respon inelastis) harus memiliki nilai lebih besar dari perpindahan leleh $\left(\Delta_{y}\right)$, $\Delta_{m}>\Delta_{y}$. Selain itu perpindahan maksimum dapat menjadi perpindahan yang mungkin dicapaipada kondisi ultimit $\Delta_{u}$ sehingga faktor daktilitas menjadi

$$
\mu_{\Delta}=\frac{\Delta_{x}}{\Delta_{y}}
$$

Dari persamaan (11) faktor daktilitas (indeks daktilitas) dapat didefinisikan sebagai rasio dari deformasi ultimit dan leleh.Selisih antara perpindahan ultimit dan perpindahan leleh adalah perpindahan plastis, $\Delta_{p}=\Delta_{w}-\Delta_{y}$. Sehingga persamaan (11) menjadi:

$$
\mu_{\Delta}=\frac{\Delta_{\mathrm{m}}}{\Delta_{\mathrm{F}}}=1+\frac{\Delta_{\mathrm{y}}}{\Delta_{\mathrm{y}}}
$$

Untuk meningkatkan faktor daktilitas perpindahan kolom maka daktilitas perpindahan plastis harus ditingkatkan dan hal ini dapat dicapai dengan pengekangan. Karena defleksi, kurvatur dan rotasi adalah sebanding dengan momen maka faktor daktilitas untuk material dapat ditulis sebagai berikut:

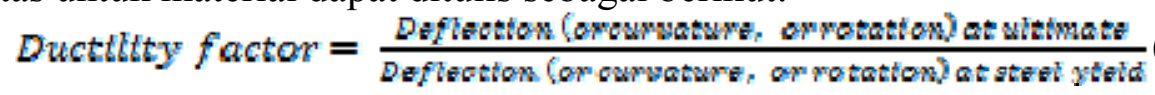

Dari perspektif desain, indeks daktilitas memberikan ukuran kemampuan penyerapan energi (Park \& Paulay, 1975).

Persamaan dibawah menunjukkan bahwa ada hubungan linear antara daktilitas kelengkungandan daktilitas perpindahan kolom. Disini juga dapat diamatibahwa panjang sendi plastis lp dan ketinggian kolom L merupakan dua faktor penting yang mempengaruhi hubungan ini.

$$
\begin{gathered}
\Delta_{t}=\Delta_{y}+\Delta_{p}=\frac{\omega_{y} L^{a}}{g}+\left(\phi-\phi_{y}\right) l_{p}\left(L-0.5 l_{p}\right) \\
\mu_{\Delta}=1+3\left(\mu_{\phi}-1\right) \frac{l_{s}}{L}\left(1-0.5 \frac{l_{p}}{L}\right) \\
\text { Dimana: } \Delta \mathrm{t}=\text { perpindahan } \\
\Delta \mathrm{y}=\text { perpindahan leleh } \\
\Delta \mathrm{p}=\text { perpindahan plastis } \\
\varphi \mathrm{y}=\text { kelengkungan leleh } \\
\varphi=\text { kelengkungan } \\
\mu \Delta=\text { daktilitas perpindahan } \\
\mu \varphi=\text { daktilitas kelengkungan }
\end{gathered}
$$

Meningkatkan daktilitas kelengkungan, pada gilirannya akanmembutuhkan meningkatkan jumlah pengekangan dengan rincian yang tepat. Oleh karena itu, persamaan (15) menunjukkan bahwa jumlah pengekangan adalah cara yang efisien untuk mengontrol kolom beton.

Kekuatan Dan Daktilitas Perpindahan Kolom Pendek Beton Bertulang Persegi Dibawah Pengaruh Pembebanan Siklik 


\section{Pembebanan Siklik}

Beban siklis merupakan beban berulang yang diterima oleh suatu struktur.Kegagalan struktur juga bisa disebabkan oleh beban siklis yang terjadi, meskipun desain awal struktur memiliki kekuatan yang memenuhi persyaratan yang ditentukan. Kegagalan akibat kelelahan struktur(fatigue)yang merupakan fenomena dimana beton pecah ketika mengalami beban berulangpada tegangan lebih kecil daripada kekuatan tekan maksimumdan kekuatan fatigueyang didefinisikan sebagaikekuatan yang dapatdidukung untuk sejumlah siklus tertentu. Fatiguedipengaruhi olehberbagai pembebanan, tingkat pembebanan, load historydan sifat material [Al-Sulayfani, 2008].

Pada struktur kolom, beban aksial merupakan representatif dari berat sendiri dan beban siklis merupakan beban luar yang terjadi berulang misalkan beban gempa. Beban aksial dan siklis ini akan bekerja secara bersamaan pada struktur kolom.

Untuk memprediksi perilaku struktur beton di bawah pembebanan seismik, model tegangan-regangan beton di bawah beban siklik (loop histeresis) adalah hal yang penting untuk diamati [Watanabe] dan digambarkan seperti gambar 3.

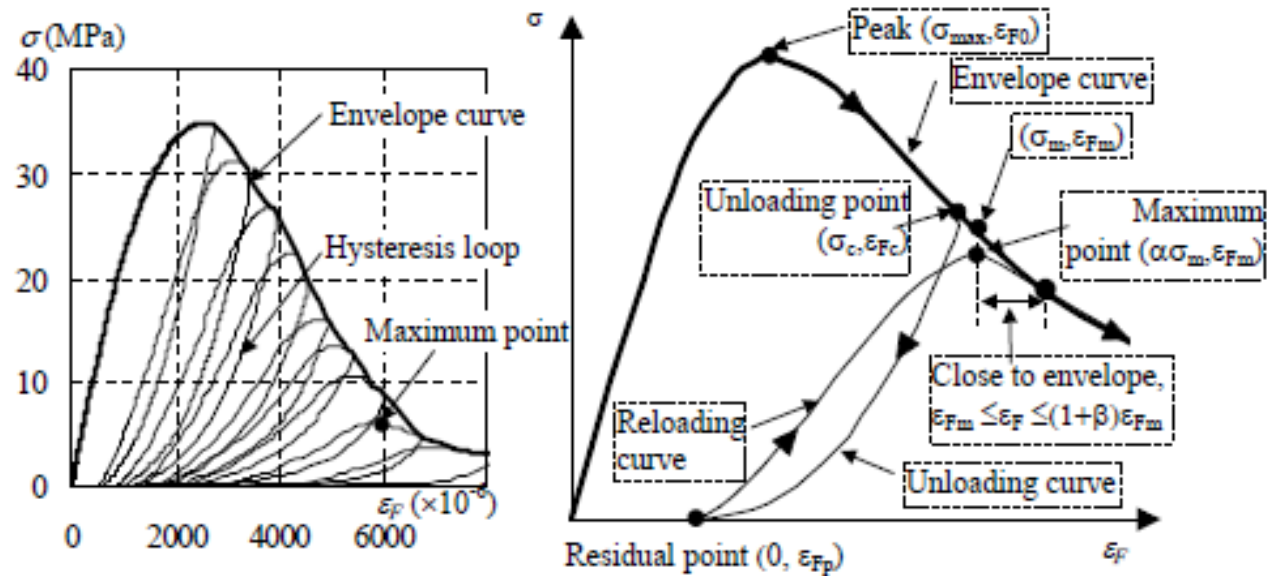

Gambar 3. Histerisis Loop

\section{METODE}

\section{Desain Benda Uji}

Spesimen yang diuji adalah 1 buah kolom persegi full scale dengan ukuran 350 x $350 \mathrm{~mm}$ dan tinggi $1100 \mathrm{~mm}$.Pada bagian bawah kolom dijepit setinggi $500 \mathrm{~mm}$. Asumsi yang digunakan adalah kolom pendek dengan tumpuan jepit-bebas.Pada bagian atas kolom dibiarkan bebas bergerak sesuai dengan beban yang bekerja. Mutu beton yang digunakan adalah $\mathrm{f}^{\prime} \mathrm{c}=20,34 \mathrm{MPa}$, mutu baja untuk tulangan longitudinal adalah fy $=549,94 \mathrm{MPa}$ dengan jumlah tulangan longitudinal 8D19 dan mutu baja untuk tulangan transversal 386,52 Mpaberdiameter tulangan $\phi 10 \mathrm{~mm}$ dengan jarak antar tulangan $200 \mathrm{~mm}$.Benda uji ditampilkan pada gambar 4 dan spesifikasi benda uji ditampilkan pada tabel 1. 


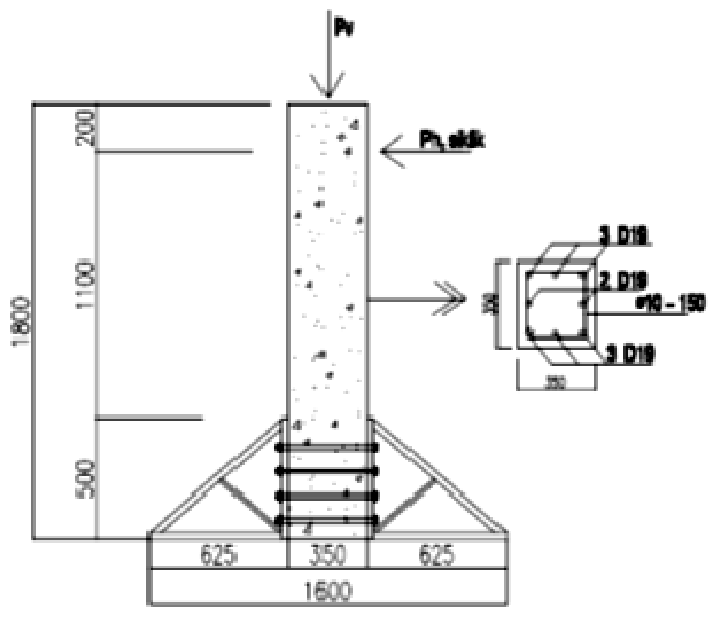

Gambar 4.Benda uji C-1

Tabel 1: Spesifikasi benda uji

\begin{tabular}{|c|c|c|c|c|c|c|c|c|c|c|}
\hline \multirow[b]{2}{*}{$\begin{array}{c}\text { No } \\
\text { Benda } \\
\text { uji } \\
\end{array}$} & \multirow[b]{2}{*}{$\begin{array}{c}\text { Benda } \\
\text { uji } \\
\text { kolom }\end{array}$} & \multirow{2}{*}{$\begin{array}{l}\text { Kuat } \\
\text { tekan } \\
\text { beton } \\
\text { (Mpa) }\end{array}$} & \multicolumn{3}{|c|}{ Ukuran Kolom } & \multicolumn{2}{|c|}{ Tulangan } & \multicolumn{3}{|c|}{ CFRP Jacketing } \\
\hline & & & $\begin{array}{c}\mathrm{B} \\
(\mathrm{mm})\end{array}$ & $\begin{array}{c}\mathrm{H} \\
(\mathrm{mm} \\
)\end{array}$ & $\begin{array}{c}\mathrm{L} \\
(\mathrm{mm} \\
)\end{array}$ & Long. & Trans. & $\begin{array}{c}\mathrm{Fu}, \\
\mathrm{MPa}\end{array}$ & $\begin{array}{c}\text { Tebal } \\
\text { / lapis } \\
(\mathrm{mm})\end{array}$ & $\begin{array}{l}\text { Jumlah } \\
\text { Lapisan }\end{array}$ \\
\hline 1 & C-1 & 20,34 & 350 & 350 & 1100 & $8 \mathrm{D} 19$ & $\varnothing 10-200$ & - & - & - \\
\hline
\end{tabular}

\section{Karakteristik Material Benda Uji Material Beton}

Beton yang direncanakan pada penelitian adalah beton normal dengan kuat tekan beton rencana 28 hari $\mathrm{fc}^{\prime}=20 \mathrm{MPa}$ dengan deviasi standar $5 \mathrm{MPa}$ serta memiliki nilai slump $(12 \pm 2) \mathrm{cm}$. Pada saat dilakukanpengecoran benda uji, dilakukan pengambilan sampel uji kontrol. Sampel uji kontrol tersebut berupa silinder yang memiliki diameter $15 \mathrm{~cm}$ dan tinggi $30 \mathrm{~cm}$. Pengujian kuat tekan beton dilakukan pada umur 7 hari, 28 hari, dan 47 hari. Hasil pengujian kuat tekan beton dapat dilihat pada Tabel 2.

Tabel 2: Hasil uji kuat tekan beton

\begin{tabular}{lccccccc}
\hline \multirow{2}{*}{ Deskripsi } & \multicolumn{6}{c}{ Kuat Tekan Beton (Mpa) } & Rata- \\
\cline { 2 - 7 } & Benda & Benda & Benda & Benda & Benda & Benda & rata \\
& Uji 1 & Uji 2 & Uji 3 & Uji 4 & Uji 5 & Uji 6 & (Mpa) \\
\hline Kuat Tekan Beton 7 hari & 12,11 & 12,39 & 12,56 & 13,41 & 11,71 & 12,73 & 12,48 \\
Kuat Tekan Beton 28 hari & 18,44 & 18,10 & 18,89 & 17,87 & 19,63 & 19,35 & 18,71 \\
Kuat Tekan Beton 47 hari & 22,29 & 22,12 & 21,55 & 21,33 & 21,49 & 20,65 & 20,34 \\
\hline
\end{tabular}

\section{Material Baja}

Baja tulangan yang dipakai untuk tulangan longitudinal adalah ulir (deform) D19 mm sedangkan tulangan transversal (sengkang) menggunakan tulangan baja polos $\phi 10 \mathrm{~mm}$. Hasil pengujian tarik tulangan baja dapat dilihat pada tabel 3. . 
Tabel 3: Hasil uji tarik baja tulangan

\begin{tabular}{lcc}
\hline \multicolumn{1}{c}{ Material baja } & $\begin{array}{c}\text { Kuat leleh } \\
(\mathrm{Mpa})\end{array}$ & $\begin{array}{c}\text { Kuat Ultimit } \\
(\mathrm{Mpa})\end{array}$ \\
\hline Tulangan ulir diameter $19 \mathrm{~mm}$ & 549,94 & 530,08 \\
Tulangan polos diameter $10 \mathrm{~mm}$ & 386,52 & 756,17 \\
\hline
\end{tabular}

\section{Instrumentasi Dan Test Setup Instrumentasi}

Strain gauge dipasang uUntuk masing-masing spesimen, Strain gaugebaja dipasang pada tulangan longitudinal sebanyak 4 buah, pada sengkang sebanyak 4 buah dan 2 buah strain gauge dipasang pada fiber pada sisi samping kiri dan kanan setinggi $500 \mathrm{~mm}$ dari dasar kolom. Khusus untuk kolom original dipasang 2 buah strain gauge untuk beton dengan posisi yang sama seperti penempatan strain gauge fiber. Pemasangan strain gauge dapat dilihat pada gambar $5 \mathrm{a}$.

LVDT dipasang untuk memonitor besarnya peralihan dan rotasi pada daerah yang ditinjau selama pengujian. Jumlah keseluruhan LVDT untuk pengujian adalah 18 buah dengan posisi masing-masing 8 buah diletakkan pada zona sendi plastis, 2 buah dibagian tengah tinggi efektif kolom, 2 buah diatas dan 6 buah dibawah sebagai kontrol alat bantu pelat baja bagian bawah.Pemasangan LVD pada benda uji dapat dilihat seperti pada gambar $5 \mathrm{~b}$.
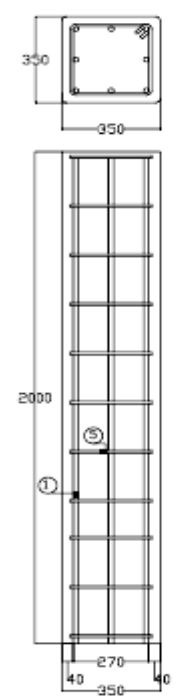

SAMPING KIRI
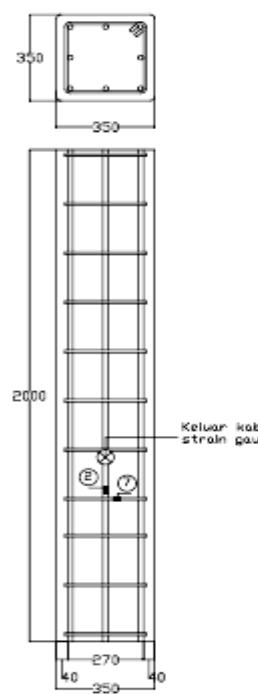

(a)

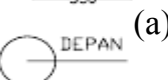

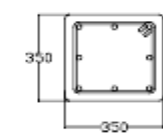

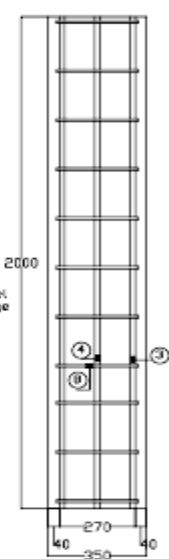

SAMPING KANAN
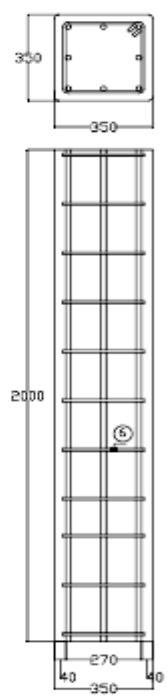

BELAKANG

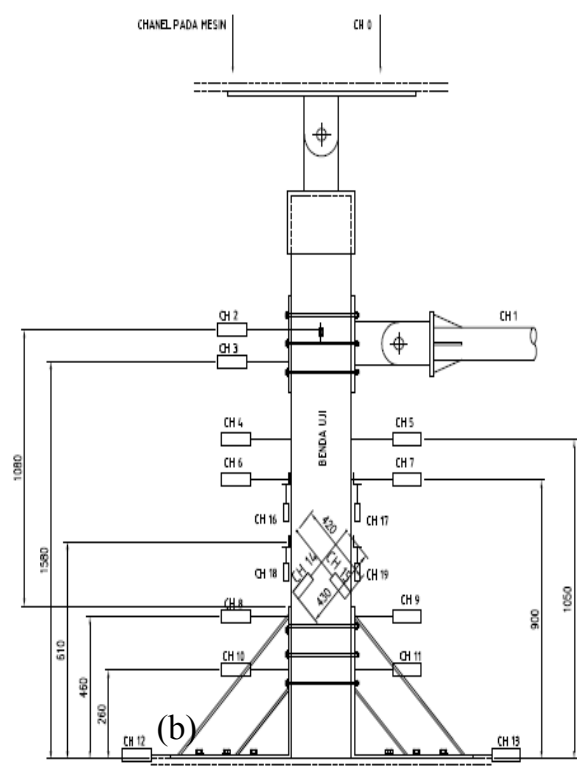

Gambar 5. (a) Pemasangan Strain gauge dan (b) Setting Up LVDT

\section{Test Setup}

Pelaksanaan pengujian dilakukan dengan menempatkan benda uji kolom berdiri tegak pada 2 (dua) buah rangka baja (loading frame) yang diletakkan diatas lantai kerja yang dikunci pada ujung-ujung balok tumpuan dengan baut. Untuk mendapatkan asumsi yangn diinginkan maka dalam penelitian ini dibuat alat bantu tambahan berupa pelat baja masing-masing diletakan pada dasar kolom, samping kolom dan pada kepala kolom. Peralatan utama yang digunakan dalam pengujian adalah loadcell, hydraulic

Kekuatan Dan Daktilitas Perpindahan Kolom Pendek Beton Bertulang Persegi Dibawah Pengaruh Pembebanan Siklik 
jack, hydraulicactuator, pompa hidrolik, strainmeter dan18 buah LVDT. Load cell yang digunakan sebanyak 3 buah yang masing-masing diletakan pada kepala kolom sebanyak 2 buah yang berfungsi sebagai pembaca beban aksial dan 1 buah load cell diletakan pada samping kolom yang berfungsi sebagai pembaca beban siklik. Test Setup pengujianditunjukkan padagambar 6 .
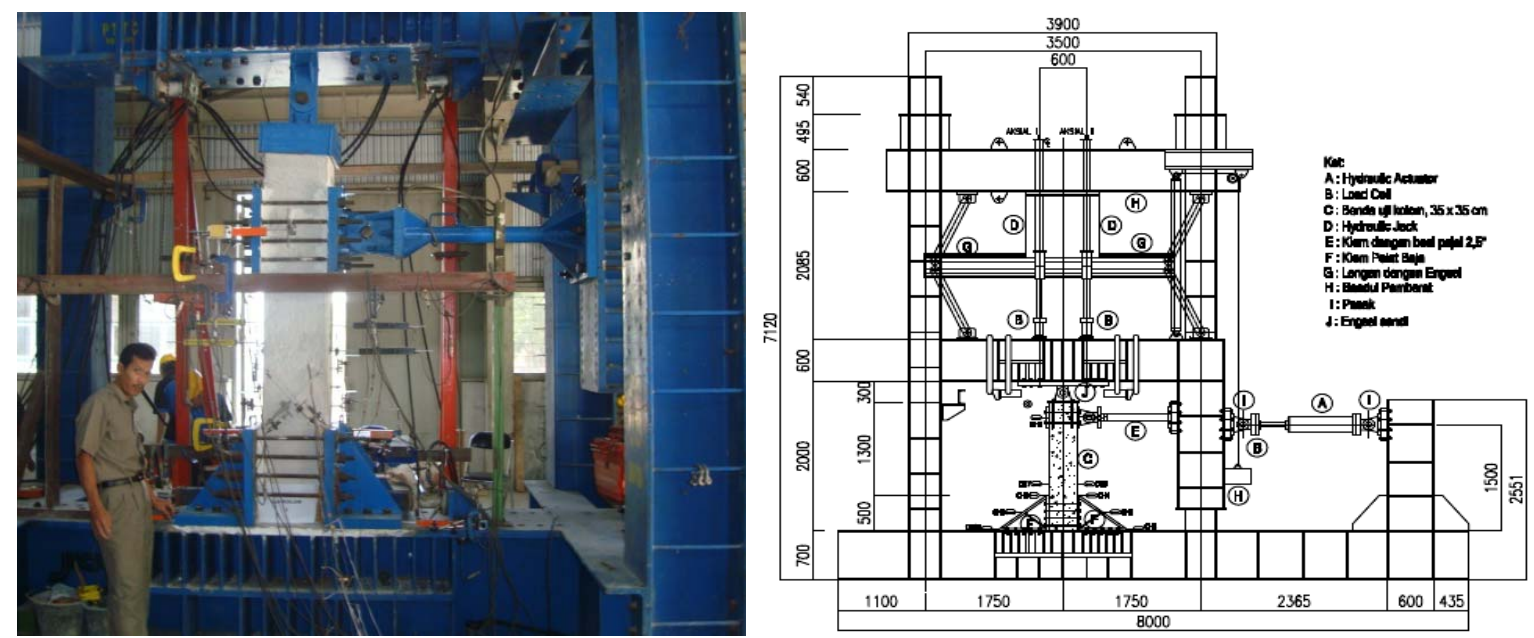

Gambar 6. Test Setup

\section{Pola Pembebanan}

Besar beban aksial yang bekerja adalah konstan sebesar $748 \mathrm{kN}$ dan dilakukan variasi untuk beban lateral siklik dengan metode displacement control. Pola pembebanan mengacu pada ACI 374.1-05 ${ }^{[4]}$ dengan rasio drift $\Delta / \mathrm{L}\left(\mathrm{x} 10^{2}\right): 0,2 ; 0,25 ; 0,35 ; 0,5 ; 0,75$; 1,$0 ; 1,4 ; 1,75 ; 2,20 ; 2,75 ; 3,5$ dan seterusnya. Pola pembebanan dapat dilihat seperti gambar 7. Pengujiandihentikansaatterjadikegagalanspecimen (failure). Pada benda uji C-1RC, untuk memberi kerusakan pada benda uji pengujian dihentikan pada drift 2,2\% selanjutnya benda uji dilakukan retrofiting dengan cara grouting dan injeksi dan setelah umur memenuhi dilanjutkan lagi proses pengujian sampai benda uji hancur.

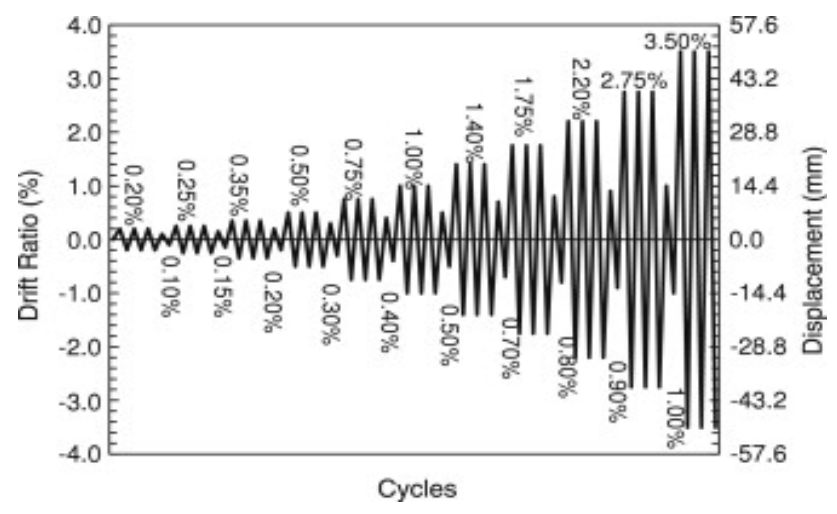

Gambar 7.Pola pembebanan

Kekuatan Dan Daktilitas Perpindahan Kolom Pendek Beton Bertulang Persegi Dibawah Pengaruh Pembebanan Siklik 


\section{PEMBAHASAN}

\section{Kekuatan Kolom Teoritis}

Perhitungan analisa kekuatan kolom teoritis untuk masing-masing benda uji diperoleh dariperhitungan diagram interaksi P-M seperti yang ditunjukkan pada Gambar 8.

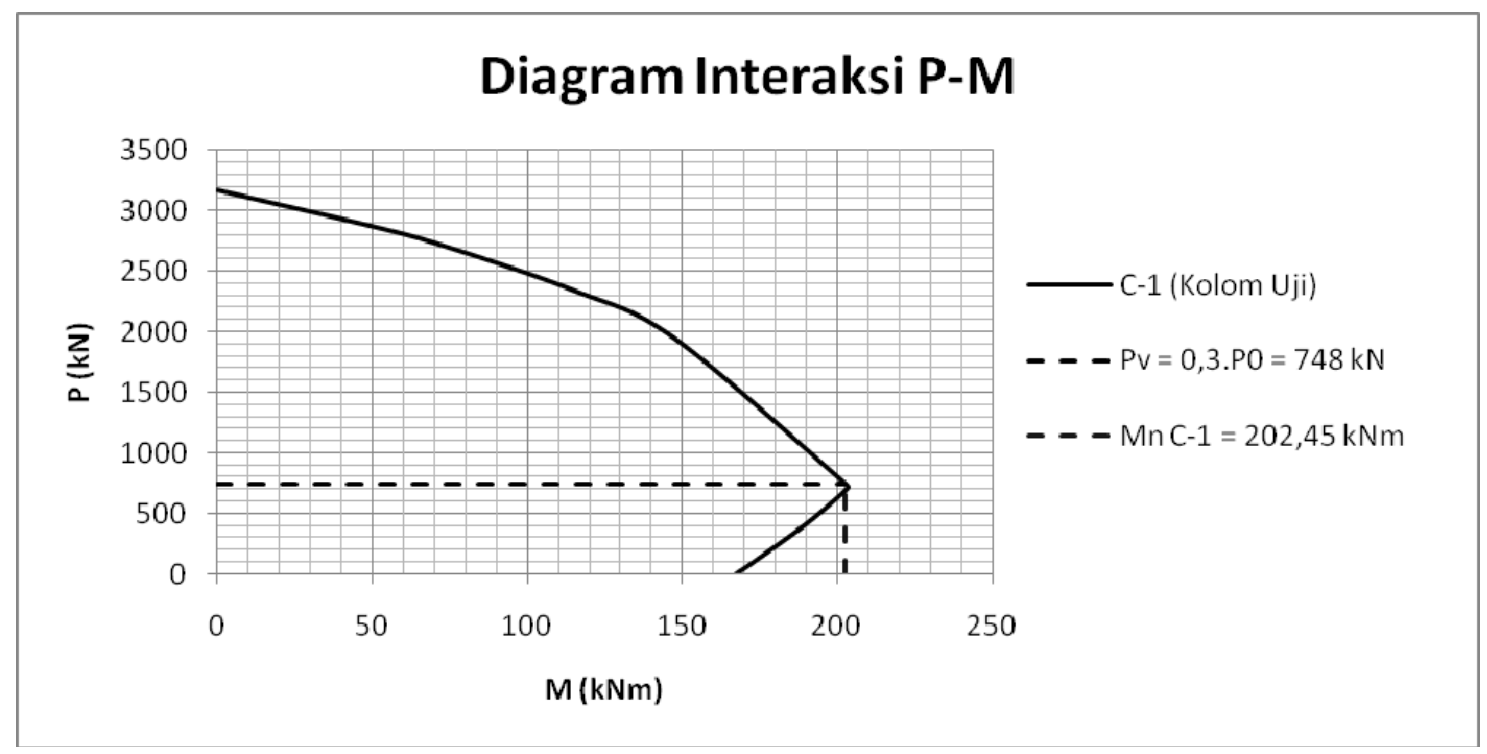

Gambar8. Diagaram Interaksi Benda Uji

Dari diagram interaksi maka diperoleh kapasitas kekuatan teoritis untuk masing-masing benda uji sebagai berikut:

Tabel 4. Perhitungan Beban Rencana

\begin{tabular}{cc}
\hline Nilai & Original Column \\
\hline $\mathrm{C}(\mathrm{mm})$ & 164 \\
$\mathrm{Pv}(\mathrm{kN})$ & 748 \\
$\mathrm{e}(\mathrm{mm})$ & 250 \\
$\mathrm{Mn}(\mathrm{kNm})$ & 202,45 \\
$\mathrm{Ph}(\mathrm{kN})$ & 185,73 \\
\hline
\end{tabular}

Dimana :

$$
\begin{array}{ll}
\mathrm{C} & =\text { Lebar bidang tekan } \\
\mathrm{Pv} & =\text { Beban/Gaya aksial } \\
\mathrm{e} & =\text { Eksentrisitas } \\
\mathrm{Mn} & =\text { Momen nominal } \\
\mathrm{Ph} & =\text { Beban/Gaya lateral }
\end{array}
$$

Beban vertikal direncanakan konstan sebesar $748 \mathrm{kN}$ hal ini sebagai simulasi beban sendiri bangunan dan beban hidup yang bekerjapada suatu struktur bangunan. Beban vertikal diambil $30 \%$ dari beban nominal yang direpresentasikan pada kolom tengah bangunan (intermediate column). Kekuatan kolom ditunjukkan oleh kapasitas 
beban horizontal $\left(\mathrm{P}_{\mathrm{h}}\right)$ dan momen yang secara teroritis diperoleh $\mathrm{P}_{\mathrm{h}}$ sebesar $185,73 \mathrm{kN}$ dan momen nominal kolom secara teoritis diperoleh 202,45 kN.m.

\section{Hasil Eksperimental}

Retak Awal, Spalling dan $\mathbf{P}_{\text {maks }}$

Pada kolom C-1 retak awal terjadi pada beban lateral sebesar $226,4 \mathrm{kN}$ di drift rasio 1,4\%. Spalling kolom terjadi pada saat beban mencapai $250,1 \mathrm{kN}$ drift rasio $2,75 \%$ yang menyebabkan tulangan longitudinal terlihat dengan jelas. $\mathrm{P}_{\text {maks }}$ terjadi pada beban lateral288,0 kN drift rasio 3,50\%. Kerusakan kolom C-1 paling parah terjadi pada zona sendi plastis sampai ketinggian $600 \mathrm{~mm}$ di atas penjepit (pondasi) kolom.Kegagalan diakibatkan spalling beton dan hancurnya inti beton serta tekuk tulangan longitudinal.Selain di zona sendi plastis, kerusakan juga terjadi pada kolom bagian atas, meskipun tidak sebesar pada zona sendi plastis.Kegagalan yang terjadi pada C-1 seperti ditampilkan pada gambar 9 .

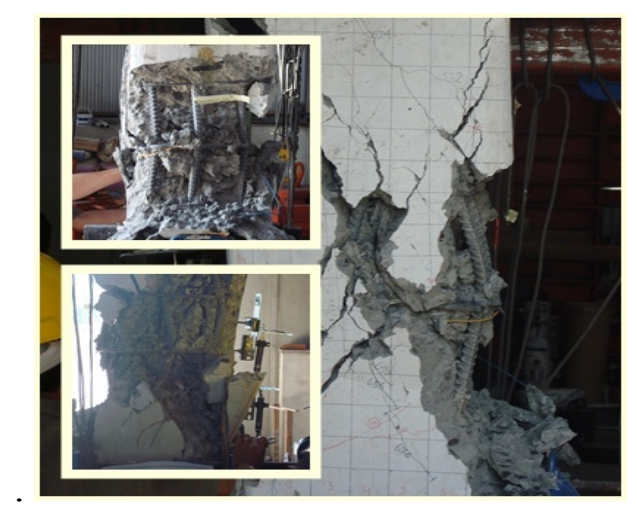

Gambar 10. Kerusakan lentur kolom C-1

Tabel 5 memberikan data beban saat terjadi retak awal, spalling dan beban maksimum.Beban saat terjadi retak awal, spalling dan beban maksimum kolom diperoleh dari hasil uji aksial-siklik.

$\underline{\text { Tabel 5. Kolom uji mengalami retak awal, spalling dan } \mathrm{P}_{\max }}$

\begin{tabular}{cccc}
\multirow{2}{*}{ Kolom Uji } & \multicolumn{3}{c}{ Beban $(\mathrm{kN})$} \\
\cline { 2 - 4 } & $\begin{array}{c}\text { Retak } \\
\text { Awal/Drift }\end{array}$ & Spalling/Drift & $\mathrm{Ph}_{\max } /$ Drift \\
\hline $\mathrm{C}-1$ & $-226,4 \mathrm{kN} / 1,4 \%$ & $-250,1 \mathrm{kN} / 2,75 \%$ & $-288,0 \mathrm{kN} / 3,5 \%$ \\
\hline
\end{tabular}

\section{Daktilitas dan Grafik Hubungan $\mathbf{P}-\Delta$}

Untuk mengukur daktilitas digunakan 2 (dua) parameter yaitu daktilitas perpindahan $(\mu \Delta)$ dan daktilitas curvature $(\mu \varphi)$. Pada pembahasan ini parameter yang digunakan adalah daktilitas perpindahan. Nilai Ultimate diperoleh dari data pengujian pada saat beban ultimate dan leleh diperoleh dari data saat baja tulangan mengalami leleh pertama kali. Nilai-nilai daktilitas untuk kolom C-1 dapat digambarkan dengan grafik skeleton sebagai berikut (gambar 11):

Kekuatan Dan Daktilitas Perpindahan Kolom Pendek Beton Bertulang Persegi Dibawah Pengaruh Pembebanan Siklik 


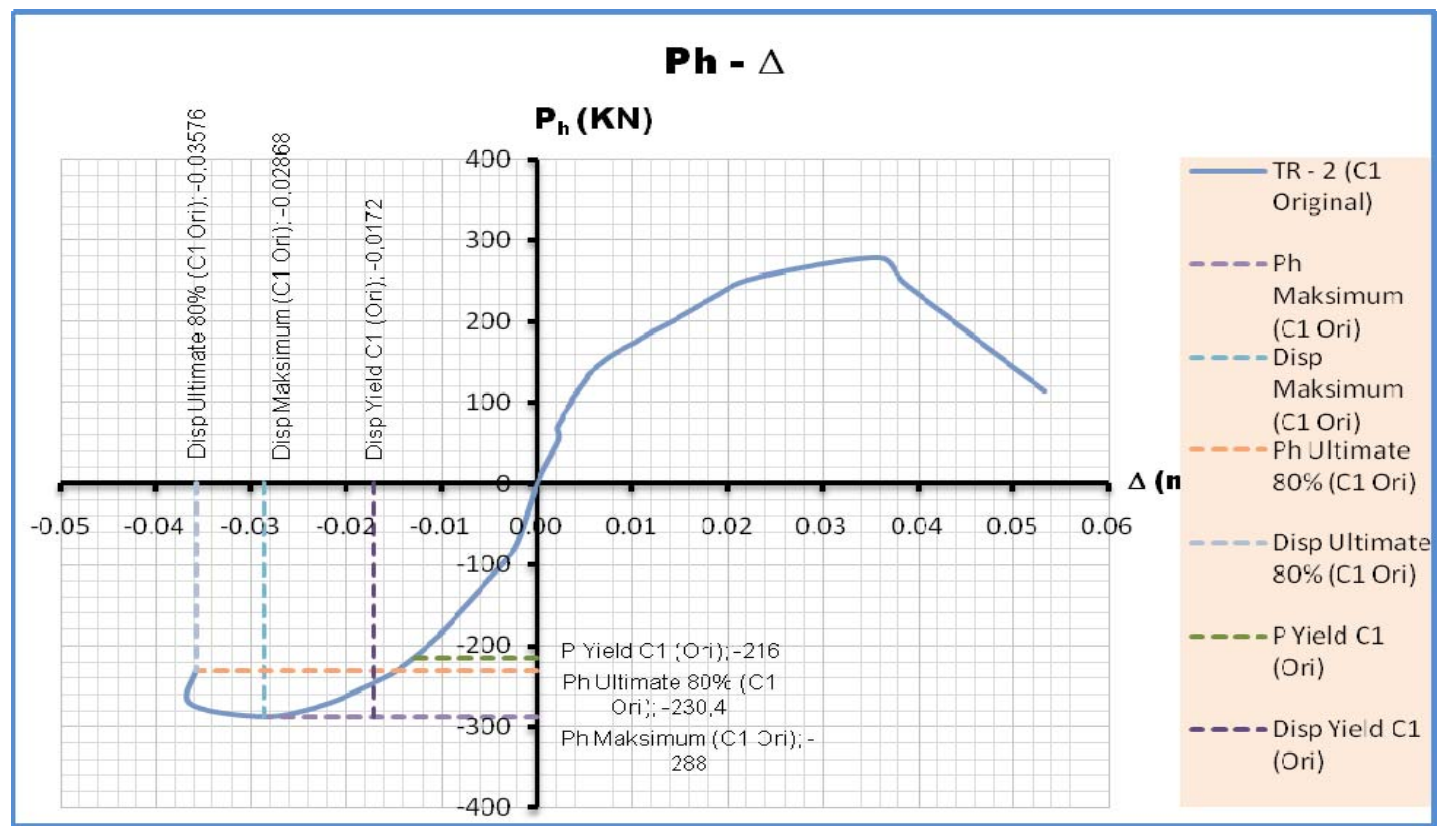

Gambar 11. Grafik Sekeleton Hubungan P - $\Delta$

Dari hasil ekperimen diperoleh nilai daktilitas perpindahan $(\mu \Delta)$ untuk C-1 sebesar 2,71. Sedangkan hubungan Beban dan Lendutan pada kolom dapat diberikan dengan gambar 12 sebagai berikut:

\section{Grafik Hubungan $P-\Delta(C-1)$}

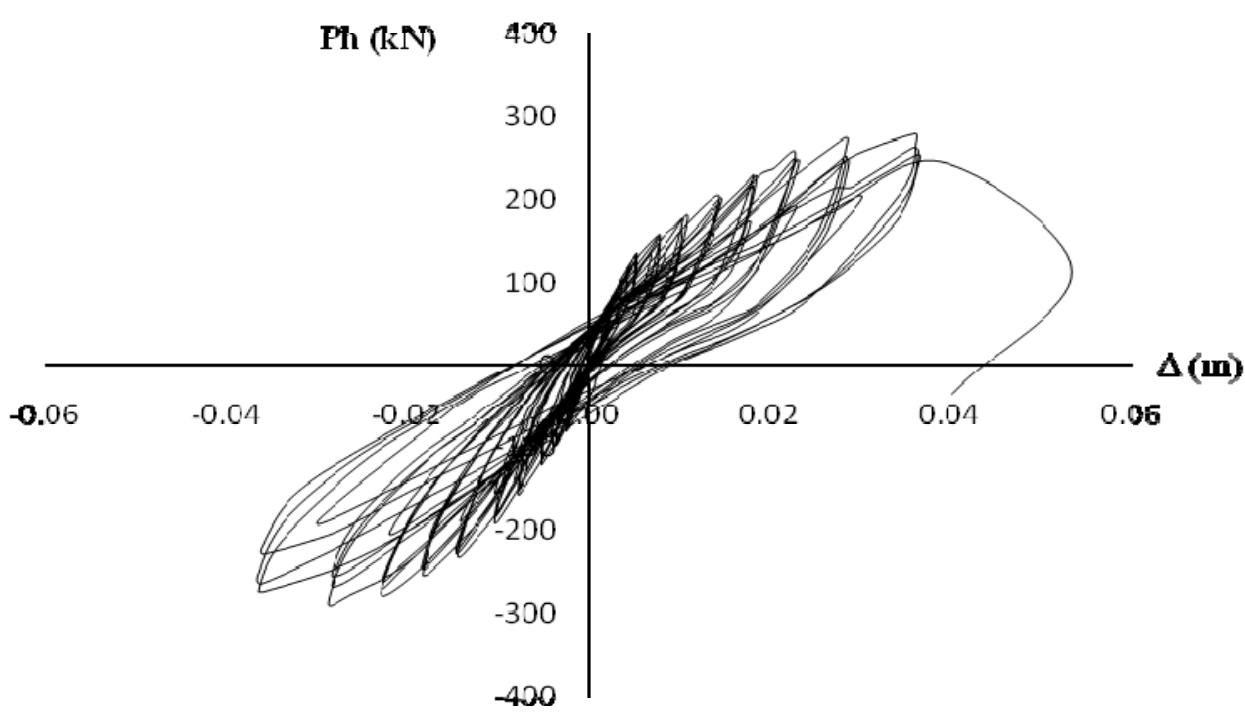

Gambar 12. Grafik Hubungan $\mathrm{P}-\Delta$ kolom $\mathrm{C}-1$

Kekuatan Dan Daktilitas Perpindahan Kolom Pendek Beton Bertulang Persegi Dibawah Pengaruh Pembebanan Siklik 


\section{KESIMPULAN}

Dari analisa teoritis diagram interaksi diperoleh nilai $\mathrm{Ph}$ (kapasitas beban lateral) sebesar $185,73 \mathrm{kN}$ momen nominal kolom secara teoritis diperoleh 202,45 kN.m sedangkan dari hasil ekperimental diperoleh $\mathrm{P}_{\mathrm{h} \text { maks }}$ sebesar 288,0 kN sehingga diperoleh momen nominal sebesar 316,8 kN.m. Nilai Daktilitas kolom diperoleh setelah benda uji dilakukan pengujian siklik dan hasil pengujian dilakukan analisis. Daktilitas perpindahan $(\mu \Delta)$ kolom uji C-1 sebesar 2,71, sehingga kolom termasuk daktail parsial.

\section{DAFTAR PUSTAKA}

Krisnamurti. "MetodeAnalisisStrukturAkibatBebanGempa" Jember University Press, Jember, 2009

Mander, J.B., Priestly, M.J.N., and Park, R., "Theoretical Stress-Strain Model for Confined Concrete", Jornal of Structural Engineering, ASCE, V. 114, No. 8, August 1988, pp. 1804-1826

McCormac, Jack. "DesainBetonBertulang” Jilid 1 EdisiKelima, PenerbitErlangga, 2003

Park, R and Paulay,T."Reinforced Concrete Structures" John Wiley and Sons, Canada, 1975

Sheikh, S., A., and Li, Y. "Design of FRP Confinement for Square Concrete Columns" Engineering Structures, 2006

Tim Revisi PetaGempa Indonesia (2010) "RingkasanHasilStudi Tim RevisiPetaGempa Indonesia 2010" Bandung.

Watanabe, K, Niwa, J, Yokota, H and Iwanami, M. "Stress-Strain Relationship for the Localized Compressive Failure Zone of Concrete under Cyclic Loading"

Kekuatan Dan Daktilitas Perpindahan Kolom Pendek Beton Bertulang Persegi Dibawah Pengaruh Pembebanan Siklik 